\title{
DOKLADY HRNČÍŘSKÉ VÝROBY V TYLOVĚ ULICI V PLANÉ U MARIÁNSKÝCH LÁZNÍ
}

\author{
JIŘÍ ORNA - ANTONÍN ZELENKA
}

\begin{abstract}
Abstrakt: Studie předkládá rozbor jedné z nálezových situaci odkrytých v rámci záchranného archeologického výzkumu vyvolaného zámérem výstavby rodinného domu v Tylově ulici v Plané u Mariánských Lázní. Na základě rozboru polohy lokality a vybraných nálezů je podpořena interpretace této situace jako odpadní deponie hrnčírské dílny. Vzhledem $k$ tomu, že šlo o výzkum záchranný, tedy v rozsahu plošně omezený, jsou nastíněny i problémy, které toto omezeni při interpretaci přináší.
\end{abstract}

Kličová slova: Planá - střepiště - figurální plastika - vyhřivací roura-keramická destička.

\section{Evidence of pottery production in Tylova Street in Planá, near Mariánské Lázně}

Abstract: This study presents the analysis of one of the contexts of finds unearthed within rescue archaeological research associated with a planned construction of a house in Tylova Street in the town of Planá, near Mariánské Lázné. The analysis of the location and selected finds supported the interpretation of the place as a disposal site of a potter's workshop. Owing to the fact that it was rescue research, i.e. spatially limited, the article also outlines problems brought by these limitations as regards interpretation.

Key words: Planá-sherd site-figurative sculpture-heating pipe-ceramic plate.

\section{Úvod}

Záchranné archeologické výzkumy reagující na záměr výstavby rodinných domů se velmi často soustředí pouze na průzkum profilů výkopů pro základové pasy těchto staveb. Tato metoda je plně v souladu se současným př́stupem, který vychází z Úmluvy o ochraně archeologického dědictví Evropy, a jsou při něm zkoumána pouze ta místa, na kterých stavební záměr vyvolává narušení archeologických nálezů. Omezený prostorový rozsah těchto výzkumů však může komplikovat interpretaci odkrytých nálezových situací. Výše uvedená metoda byla použita také

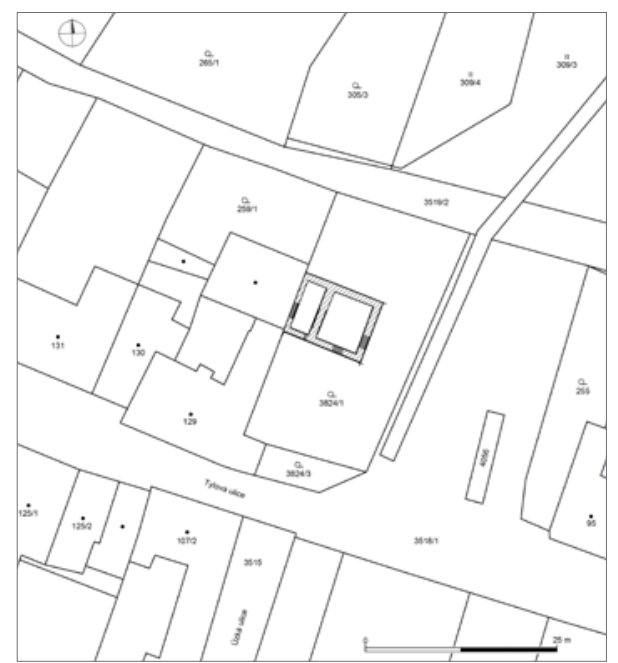

Obr. 1. Planá - výřez z katastrální mapy s vyznačením rozsahu záchranného archeologického výzkumu, zkoumané základové pasy vyznačeny šrafurou. Autorka L. Ornová. Abb. 1. Planá - Ausschnitt aus der Katasterkarte mit Kennzeichnung des Umfangs der archäologischen Rettungsgrabung, die untersuchten Fundamentstreifen sind schraffiert dargestellt. Erstellt von L. Ornová. v záŕí 2017 při výzkumu vyvolaném záměrem výstavby rodinného domu na pozemku s parcelním číslem 3824/1 v Tylově ulici v Plané u Mariánských Lázní. Přes nepř́liš velký rozsah (obr. 1) výzkum realizovaný oddělením prehistorie Západočeského muzea v Plzni přinesl několik zajímavých zjištění a poznatků (Zelenka 2018, 38-39). Rozbor jedné z nálezových situací doloží již zmíněné problémy, které při interpretaci přináší plošné omezení výzkumu.

\section{Stručný nástin historie lokality v období středověku}

Město Planá leží necelých 50 km severozápadně od Plzně. První osídlení se v místě větvení starých cest od Teplé či Plzně na Waldsassen a Cheb objevuje již v období raného středověku. Archeologické výzkumy Západočeského muzea v Plzni doložily v severní části města osídlení již na přelomu 8. a 9. století (Bašta 1991, 70-71; Frýda 1978, 63), u kostela 


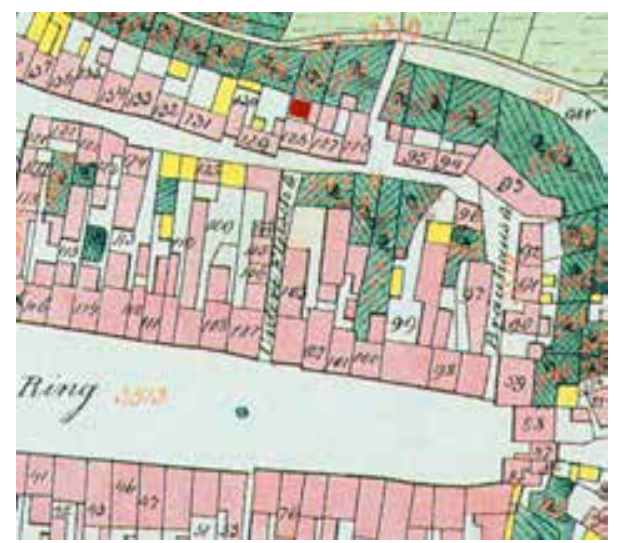

Obr. 2. Vyznačení parcely dotčené výzkumem na mapě stabilního katastru z let 1824-1843. Upravila L. Ornová. Abb. 2. Kennzeichnung der Parzelle der betreffenden Grabung auf einer Karte des Stabilen Katasters von 18241843. Bearbeitet von L. Ornová. sv. Petra a Pavla v 10. a 11. století (Hanzlíková-Frýda 1982, 425). Osada Planá je k roku 1219 zmiňována jako majetek tepelského kláštera (Senft 1932, 16), spíše se však jedná o ves Pláň u Bezdružic (Procházka 2002, 81). Každopádně před polovinou 13. století se stala osada zeměpanským majetkem, v roce 1251 svěřil Václav I. patronátní práva ke kostelu v Plané waldsassenskému klášteru (RBM I, 587). Otázkou je, o jaký kostel se jednalo, nebot' $\mathrm{v}$ té době existoval nejen již zmíněný kostel sv. Petra a Pavla na východním předměstí, ale také kostel Nanebevzetí Panny Marie na jižním okraji historického jádra Plané, jehož vznik je možné na základě stavebně historického průzkumu datovat před polovinu 13. století (Líbal-Jiříková-Heroutová 1971, 11). Stavba tohoto kostela je dávána do souvislosti se vznikem města (Kuča 2002, 157). V tomto období, tedy kolem poloviny 13. století, mělo také dojít k výstavbě hradu situovaného na západním okraji plánské ostrožny (Procházka-Úlovec 1990, 108). V roce 1343 je Planá uváděna jako majetek Dobrohosta z Plané (Kuča 2002, 153). Jako městečko je Planá zmiňována $\mathrm{k}$ roku $1379 \mathrm{v}$ souvislosti s udělením městských práv a výsad (Pelant 1984, 218). Na konci 14. století se stal majitelem městečka rytíŕ Bořivoj ze Svinař, před rokem 1407 se dostalo do majetku Jindřicha z Elsterberka a na konci husitských válek se jej zmocnili páni ze Žeberka (Pelant 1984, 219).

Parcela, na které proběhl záchranný archeologický výzkum vyvolaný stavbou rodinného domu, se nachází při severním okraji historického centra, v př́íhradebním prostoru. Na mapě stabilního katastru z let 1824-1843 pozemek leží za domem čp. 128 obráceným do dnešní Tylovy ulice (pův. Fleischgasse) probíhající paralelně s hlavním náměstím (obr. 2).

\section{Popis nálezové situace}

V základovém pasu situovaném v jižní části zkoumané plochy bylo v rámci evidence nadložní stratigrafické situace zachyceno mocné souvrství hlinitých vrstev obsahujících četné zlomky keramiky a nádobkových kachlů (vrstvy 7, 20; obr. 3). Toto souvrství obsahovalo také drobné kousky mazanice. Př́tomnost mazanice zpravidla vede k označení odkryté situace jako spáleništní. Pokud se jedná o doklady zániku dřevohlinité zástavby katastrofálním požárem, jsou na zlomcích mazanice patrné otisky dřevěných konstrukčních prvků, případně je viditelná úprava vnější strany omazu hlazením. Nálezy deponií stavební mazanice a většího množství keramiky zpravidla souvisí s likvidací pozůstatků dřevohlinité zástavby zaniklé následkem katastrofálních požárů (Dudková-Orna 2007; Dudková-Orna-Netolický 2015, 19-20). Subtilnější úlomky mazanice dokládají spíše činnost pyrotechnických zařízení. Pokud jsou tyto drobné úlomky mazanice součástí objemných uloženin tvořených převážně keramickými zlomky, mohlo by se jednat se o tzv. střepiště, tedy odpadní areál hrnčířské dílny. Střepiště vznikala přemistováním odpadu z výroby od pece do prostoru, kde velký objem keramických zlomků nepřekážel provozu a komunikaci. Přesto se nedá předpokládat jeho transport na větší vzdálenost, deponování zpravidla probíhalo $\mathrm{v}$ rámci parcely.

Keramiku nalezenou v uloženině označené za střepiště je možné na základě výzdoby tvořené červeným malováním a linkami radýlkovaného dekoru a okrajů tvarovaných do tzv. okruží (obr. 4) chronologicky zařadit do období po polovině 14 . století. 


\section{Doklady činnosti hrnčířské dílny}

Při záchranném archeologickém výzkumu se nepodařilo zachytit zásadní indicii pro interpretaci odkryté situace jako hrnčířské dílny, tedy vypalovací pec. Činnost hrnčíře na parcele dotčené výzkumem není možné doložit ani pomocí písemných pramenů. Bylo proto nutné hledat další indicie, které by podpořily předpoklad, že se jedná o odkryv střepiště hrnčířské dílny.

\section{Poloha lokality}

Jak již bylo zmíněno, parcela dotčená výzkumem leží na severním okraji historického centra, v prostoru přiléhajícím $\mathrm{k}$ městské fortifikaci. Obdobnou lokalizaci hrnčířských dílen je v Čechách možné pomocí archeologie sledovat na celé řadě lokalit. Do 14. století jsou datována archeologicky zkoumaná odpadní střepiště, která dokládají keramickou výrobu na parcelách čp. 184 a ppč. 200 na západním okraji historického jádra Plzně (Nováček-Široký 2004，29). Archeologické i písemné prameny dokládají hrnčířské dílny v Rakovníku u hradeb severně od náměstí (Blažková-Lomecká 2006, 914). Deponie odpadu z hrnčířské výroby na hranici středověkého městského jádra byla archeologickým výzkumem zachycena $v$ Hořovicích (Reichertová 1962), keramická pec odkryta v Bakově nad Jizerou (Hrdlička 1967, 510). V blízkosti městských hradeb jsou hrnčířská pracoviště doložena také v Praze na Malé Straně (Havrda-Matějková 2014, 47) a na náměstí Republiky na Novém Městě (Kašpar-Žeglitz 2009, 79-83). Střepiště bylo zřejmě zachyceno i na východní straně historického centra Berouna (Sommer 1979, 44; Vařeka 2004).

\section{Drobná figurální plastika}

Mezi zlomky keramických nádob se podařilo objevit také torzo drobné figurální plastiky s dochovanou výškou $62 \mathrm{~mm}$ (obr. 5,6 ). Figurka představuje postavu oblečenou v dlouhém splývavém šatu, s rukama volně sepjatýma na břichu. Ramena zdobí volánkový lem. Podobně dekorativně je ztvárněna také knoflíková léga, ta je však vyvedena velmi nevýrazně. Podle polohy rukou a provedení

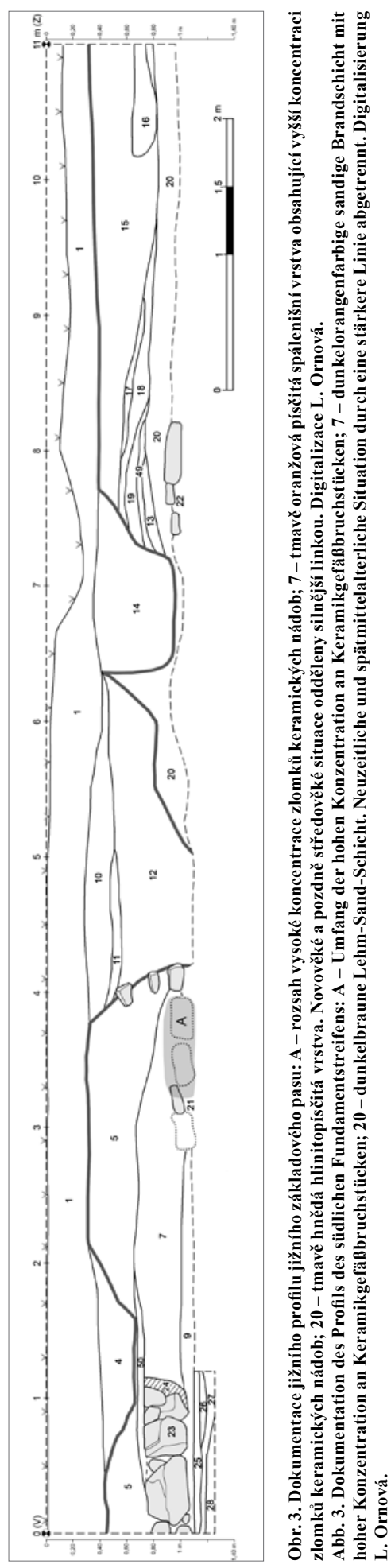




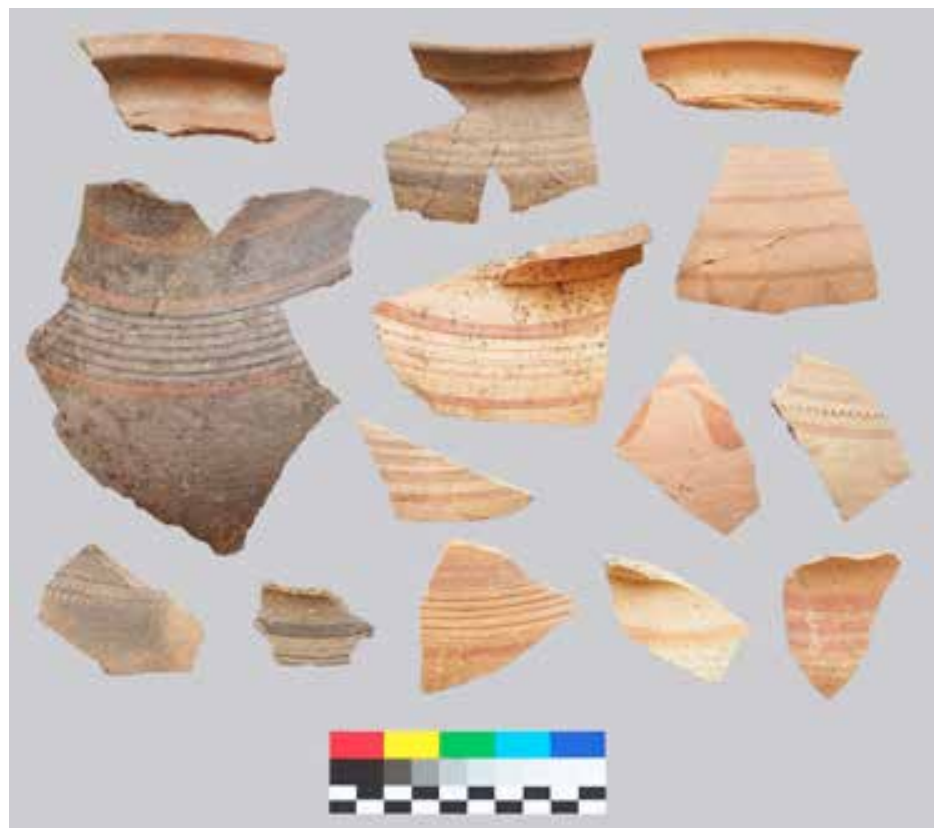

Obr. 4. Fotodokumentace výběru nalezené keramiky. Autorka L. Ornová.

Abb. 4. Fotodokumentation einer Auswahl an gefundener Keramik. Zusammengestellt von L. Ornová.

oděvu lze předpokládat, že jde o zachycení ženské postavy typu Kruseler, pojmenované podle charakteristického dobového čepce. Podle dochovaného volánkového lemu na ramenou mohl typ čepce odpovídat variantě C podle G. Grimma (2011, 44, Abb. 14) a variantě 2 podle V. Hoffmannové (1996, 145, Abb. 6).

Tyto figurky byly rozšířené v prostoru střední Evropy a měly sloužit jako pomůcka pro znázornění př́iběhů a dějů (Hoffmann 1996, 133). Nalezená figurka má odlomenou hlavu, takže zařazení do typu Kruseler je možné pouze na základě výše uvedených znaků. Stejnou polohu rukou mají například figurky z Chebu (Šebesta 1979, obr. 1, 2), Plzně (Orna 2006, 207, obr. 2) a z moravských lokalit Bystrý, Bystřec a Seloutky (Měchurová 1988, tab. II, 1, 2, 4).

Odlomení hlavy je u tohoto druhu figurální plastiky poměrně časté, a nemusí jít o důsledek jejich používání. Odlomené hlavičky byly nalezeny při výzkumu hrnčiřských dílen v Sezimově Ústí (Richter-Hrdlička 1965, 665; Hrdlička-Richter-Smetánka 1966, 670, obr. 201), kde je jejich výroba v letech 1400-1420 doložena nálezem formy (Richter 1978, tab. 17). Další pak byly objeveny při výzkumu výrobního centra na Pražském předměstí v Českých Budějovicích (Militký 1996, 4-7, 14, 16, 17).

Drobná figurální plastika mohla být modelována volně v ruce, nebo vznikala vtlačováním keramické hmoty do jedno- nebo dvoudílných forem. Dvoudílná forma byla požívána na výrobu plně plastické figury. Pro výrobu figurek ženské postavy typu Kruseler se používaly jednodílné formy, ručně byl dotvářen pouze volánkový lem na ramenou (Měchurová 2016, 43). Přestože plastika nalezená při výzkumu v Plané vykazuje znaky, které ji umožňují zařadit do typu Kruseler, je pojata plně plasticky. Při makroskopickém zkoumání vnějšího i vnitřního povrchu nebyly zaznamenány žádné stopy po výrobě ve formě, přestože v rozsáhlém nálezovém souboru drobné figurální plastiky z benediktinského kláštera sv. Ulricha a sv. Afry v německém Augsburgu je na figurkách patrné nedůkladné začištění spojů jednotlivých částí, někdy došlo 


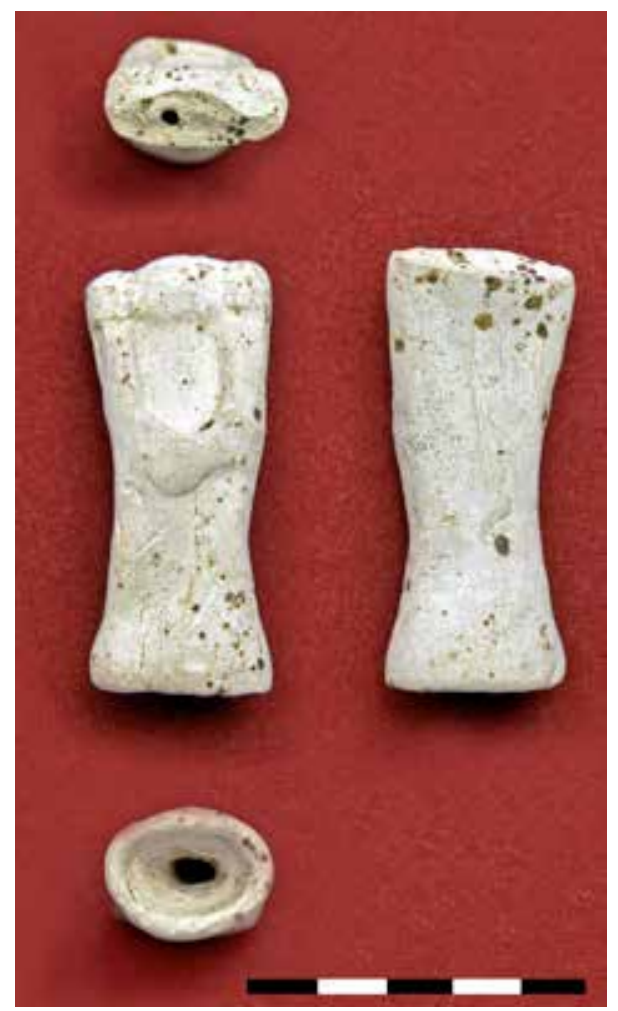

Obr. 5. Fotodokumentace nalezené drobné keramické plastiky. Autorky I. Šlechtová a M. Zemánková.

Abb. 5. Fotodokumentation der gefundenen kleinen Keramikplastiken. I. Šlechtová und M. Zemánková.

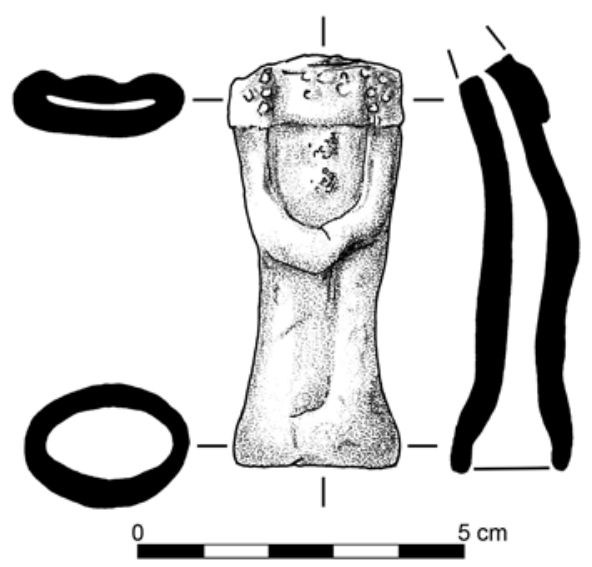

Obr. 6. Kresebná dokumentace nalezené drobné keramické plastiky. Kresba P. Peterková, finální úprava L. Ornová. Abb. 6. Zeichendokumentation der gefundenen kleinen Keramikplastiken. Zeichnung P. Peterková, Endbearbeitung L. Ornová. i k posunu přední a zadní části figurek (Hermann 2004, 16, 17). Na plastice z Plané jsou patrné stopy po tvarování a uhlazování povrchu prsty hrnčíře. Figurka typu Kruseler vyrobená $v$ ruce bez použití formy byla nalezena v Újezdě u Tišnova a působí jako nepříliš povedená nápodoba kvalitně provedených předloh (Měchurová 1988, 74; 2016, 120, obr. 52). Další z ruky modelované ženské figurky jsou známy z výzkumu hrnčířských dílen v Sezimově Ústí (Richter 1978, obr. 18) a v Hrnčířrské čtvrti v České Lípě (Gabriel-Kracíková 2010, 225, 226, obr. 1).

$\mathrm{V}$ podstavě figurky je otvor, který vede celým tělem a je patrný i v místě odlomení hlavy. V současné době se tyto otvory považují za technologické průduchy, které měly při výpalu snižovat pnutí keramické hmoty (Gerlach 1998, 206, 207).

Pro výrobu figurální plastiky byl použit materiál typický pro tento keramický produkt - jemně plavená hlína vypálená oxidačním způsobem do světle bělavého odstínu. Připomíná keramickou tř́́du v plzeňském prostředí označovanou jako „Pfeifentonware“ (Orna 2002, 182).

V českém prostředí existuje řada dokladů lokální výroby figurek typu Kruseler, které se odlišují od někdy až typizované produkce zejména německého prostředí. Zmíněny již byly nálezy v ruce tvarovaných figurek. Jedna z nich, získaná při výzkumu Hrnčířské čtvrti v České Lípě, byla zdobena červeným malováním (Gabriel-Kracíková 2010, 226, obr. 1), které se na tomto typu plastik vyskytuje poměrně výjimečně. V zaniklé středověké osadě Stará Ves v Kralicích na Moravě se během záchranného archeologického výzkumu podařilo objevit hlavu a poprsí terakotové plastiky typu Kruseler (Fojtík 2010), tedy ze zcela odlišného druhu keramické hmoty, než byla obvykle používána. Výjimečný doklad glazování panenek typu Kruseler pochází z výzkumu na náměstí Republiky v Praze (Juřinová 2015, kat. 28, tab. 11:4).

\section{Keramická destička}

Dalším artefaktem, který byl součástí deponovaného odpadu $\mathrm{z}$ hrnčířské výroby, byly fragmenty keramické destičky. Ta byla vyrobena $\mathrm{z}$ totožného materiálu jako 
keramická plastika, tedy z jemně plavené hlíny vypálené oxidačním způsobem do světle bělavého odstínu. Na heraldicky levé straně destičky jsou vloženy aversy, na heraldicky pravé reversy pozitivů pražských grošů ražených za vlády Jana Lucemburského (obr. 7, 8). Mince jsou zachyceny $\mathrm{v}$ reálné velikosti. Plát hlíny nepravidelného obdélného tvaru, z kterého byla destička vyrobena, byl zhruba uprostřed vertikálně naříznut. Toto naříznutí mělo zřejmě usnadnit rozlomení destičky po výpalu. Na spodní straně destičky jsou patrné stopy po nerovnostech podložky a odříznutí destičky od podložky. Okraje nejsou příliš propracované, na delší straně byly patrně vytvořeny pomocí dřevěné lišty, kratší strany byly zřejmě formovány pomocí špachtle. Metricky je možné určit šířku destičky (97 mm) a její sílu (13-14 mm).

Otázkou zůstává, k čemu tato destička sloužila. Vzhledem k tomu, že jsou na jejím reliéfu pozitivy mincí, lze vyloučit snahu o výrobu jejich falz. Svým provedením sice artefakt připomíná keramické formy určené k odlévání kulek, tento účel by ale znesnadňovala absence čepů a otvorů. Při hledání účelu tohoto artefaktu může pomoci nález ze saského Freibergu. Ten představuje avers i revers freibergské mince s erbem mincovny Hanse Wellera z Molsdorfu z roku 1545. Reliéfy mince jsou kvalitně a detailně vedle sebe vyřezány do březové kůry (Gühne 1991, 66, Abb. 37:7, 101, 31:13). V publikaci není objasněno, k čemu mohl tento nález sloužit. Vzhledem k tomu, že artefakty nalezené v Plané i ve Freibergu na sobě nesou vyobrazení mince, nabízí se možnost, že mince byly použity pro snadné porovnání předlohy a jejího zachycení v keramické či dřevěné podobě. Mohlo tedy jít o výstup nějaké zkoušky. V úvahu připadá například mistrovský kus.

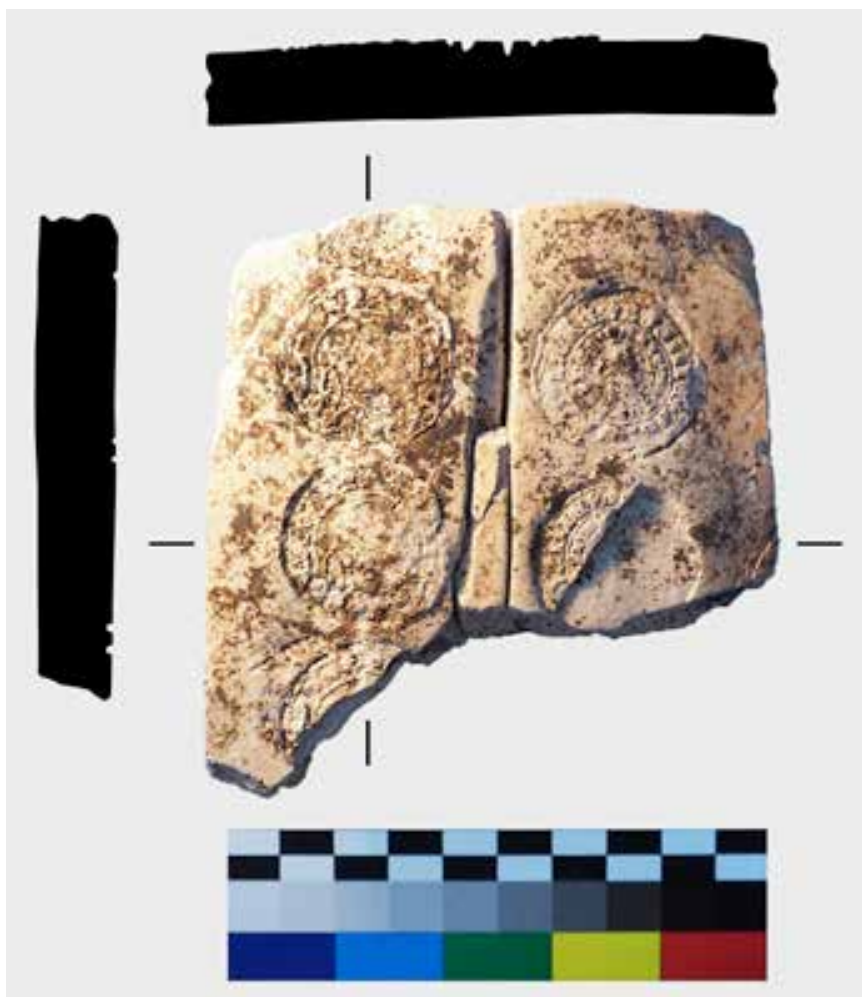

Obr. 7. Fotodokumentace nalezených fragmentů keramické destičky s kresebnou dokumentací profilů. Foto M. Zemánková, kresba P. Peterková, finální úprava L. Ornová.

Abb. 7. Fotodokumentation der gefundenen Keramikplättchenfragmente mit Zeichendokumentation der Profile. Foto M. Zemánková, Zeichnung P. Peterková, Endbearbeitung L. Ornová. 

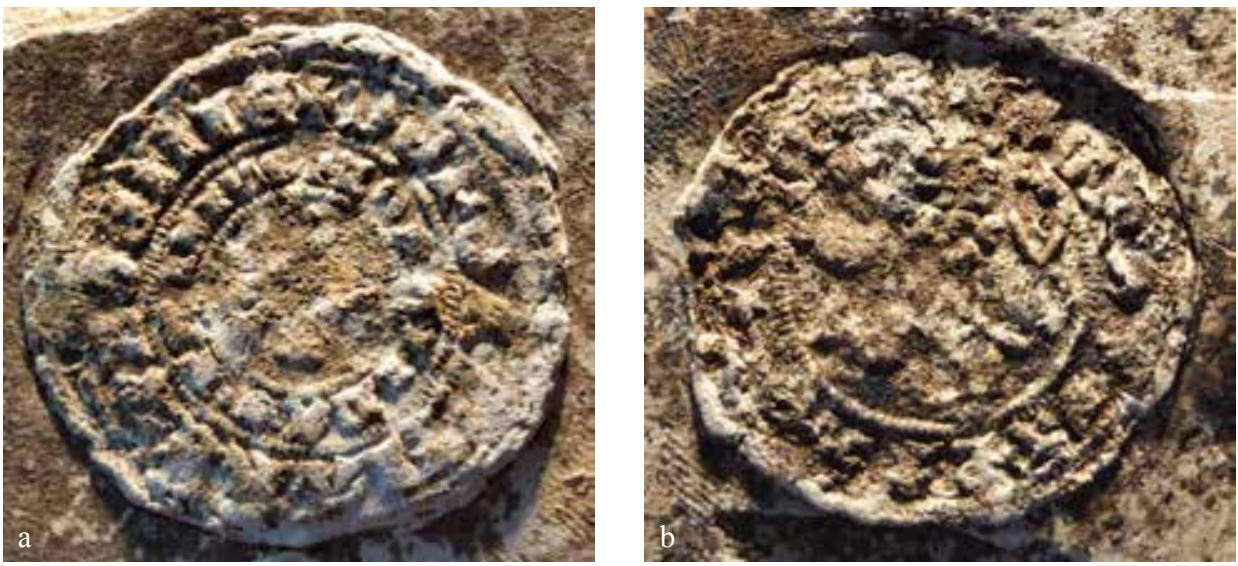

Obr. 8. a, b - detaily aversu a reversu pražských grošů na keramické destičce. Autorka M. Zemánková.

Abb. 8. a, b - Details des Avers und Revers von Prager Groschen auf dem Keramikplättchen. M. Zemánková.

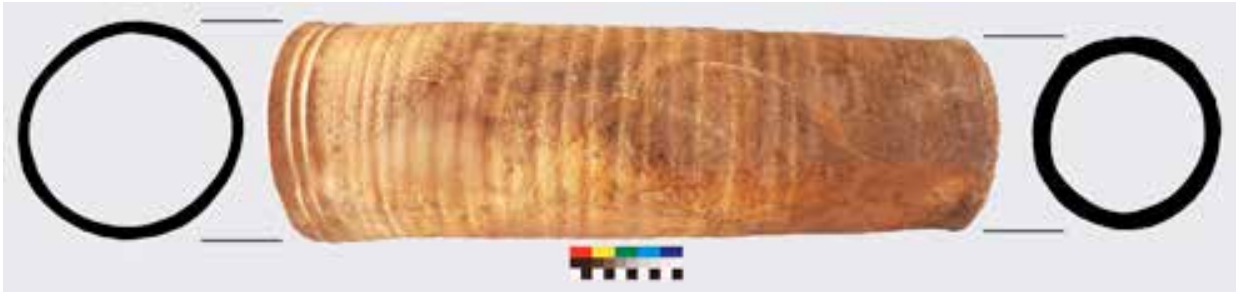

Obr. 9. Fotodokumentace nalezené keramické roury s vyznačením průřezu. Kresba P. Peterková, foto a finální úprava L. Ornová.

Abb. 9. Fotodokumentation des gefundenen Keramikrohrs mit Kennzeichnung des Querschnitts. Zeichnung P. Peterková, Foto und Endgestaltung L. Ornová.

Ze statut hrnčířského cechu ve Znojmě z roku 1520 jsou známy požadavky na mistrovský kus, kdy bylo třeba zhotovit pět výrobků (Nekuda-Reichertová 1968, 27). Nelze však vyloučit, že ve starších obdobích nemusely být nároky na mistrovský kus takto standardizované.

\section{Keramická roura}

Za doklad hrnčiřské výroby je zřejmě možné označit i nález keramické roury (obr. 9). Tělo roury je pokryté podobnou mazanicí, která byla součástí uloženiny střepiště. Nelze však plnohodnotně rozhodnout, zda k ulpění mazanice došlo ve fázi výroby, nebo při zasazení do kamnového tělesa. Při výpalu mohly vzniknout i pásy očazení na vnějším plášti. Délka roury je $60 \mathrm{~cm}$, vnější průměr $16,2 \mathrm{~cm}$ u okraje roury formovaného do tvaru okruží, $15 \mathrm{~cm}$ u okoseného okraje. Tělo je pokryto vývalkovou šroubovicí.

V současné době jsou tyto roury interpretovány jako vyhř́ívací trubice zasazené do tělesa kachlových kamen (Tymonová 2003, 585; Beutmann 2007, 81-82; Šulc-Kypta-Ježek 2009, 698-703). Nalezený exemplář z Plané se metricky shoduje s nálezy z hradu v Náměšti na Hané a ze zaniklé kartouzy v Dolanech u Olomouce (Tymonová 2003, 584-585, obr. 6, 7), ze saského Cvikova (Beutmann 2007, 81-82) a dolnosaského Einbecku (Heege ed. 2002, 264).

Užívání tohoto typu technické keramiky v domácnostech Plané u Mariánských Lázní dokládá nález torza takřka totožné vyhřívací roury v ploše situované u severní stěny kostela 
Nanebevzetí Panny Marie (Rayman 2010, obr. 4:1). Autorem výzkumu jsou uloženiny, jejichž součástí roura byla, interpretovány jako doklady zániku domů v období druhé poloviny 14. století (Rayman 2010, 4).

\section{Závěr}

Při záchranném archeologickém výzkumu vyvolaném záměrem výstavby rodinného domu v Tylově ulici v Plané u Mariánských Lázní byla jedna z odkrytých nálezových situací interpretována jako střepiště hrnčířské dílny. Vzhledem $\mathrm{k}$ absenci zásadní nálezové komponenty dokládající hrnčířskou výrobu, tedy vypalovací pece, proběhl rozbor nálezů ze střepiště a polohy lokality s cílem najít indicie dokládající činnost dílny na výrobu keramiky.

Zkoumaná parcela leží na okraji historického jádra města. V obdobné poloze na okraji historického jádra, případně v blízkosti fortifikace, se archeologicky doložené hrnčířské dílny nacházely i v řadě dalších lokalit (např. Plzeň, Rakovník, Hořovice, Bakov nad Jizerou, Beroun, Praha - Malá Strana, Praha - Nové Město), zejména pak v období 14. století. Umístění hrnčíř ských dílen na okraj města omezovalo riziko požáru, v tomto prostoru byla často řidší zástavba než ve středu města (Žegklitz 1990, 215). V dalším průběhu pozdního středověku často dochází $\mathrm{k}$ přesunu hrnčířských dílen na předměstí. Důvodem je protipožární prevence a snazší dostupnost surovin a vody (Preusz-Čapek 2019, 195).

Nalezené zlomky kuchyňské a stolní keramiky umožňují soubor chronologicky zařadit do období po polovině 14. století. Právě v tomto období začíná výroba ženských figurek typu Kruseler (Měchurová 2016, 43). Atypická výroba nalezené plastiky typu Kruseler modelací v ruce mohla být reakcí tvůrce na nově se vyskytující keramický produkt, možná se snahou o vytvoření formy pro další výrobu této figurky. Výrobu forem na drobnou figurální plastiku přímo v hrnčířské dílně doložil výzkum v německém Bad-Königshofenu (Gerlach 1998, 207-209). Pro hrnčířskou dílnu, jejíž produkci se podařilo zachytit v průběhu výzkumu v Tylově ulici v Plané, představovala výroba drobné keramické plastiky zřejmě jen marginální část produkce. Tomu ostatně nasvědčuje i provedení nalezené figurky.

Také keramická destička s pozitivy pražských grošů ražených za vlády Jana Lucemburského (1310-1346) chronologicky nijak výrazně nevybočuje z datování celého nálezového souboru. Přestože je u pražských grošů možné v rámci jejich typologie i přesnější chronologické určení (Hána 2007), kvalita provedení reliéfu mince na keramické destičce toto zpřesnění neumožňuje. Interpretace účelu destičky je poměrně obtížná, v úvahu snad připadá mistrovský kus.

Keramické vyhřívací roury se mohly používat v konstrukci kachlových kamen už od 13. století (Šulc-Kypta-Ježek 2009, 703). V českých zemích jsou nejstarší nálezy těchto rour doloženy z kartuziánského kláštera v Dolanech u Olomouce (Burian 1963, 203; 1966, 14), zaniklého v roce 1425 (Vrána 2002, 19). Výrobu této technické keramiky v Plané u Mariánských Lázní v období kolem poloviny 14 . století dokládá také nález ze zástavby zaniklé v prostoru severně od kostela Nanebevzetí Panny Marie ve druhé polovině tohoto věku.

Střepiště zachycené záchranným archeologickým výzkumem v Tylově ulici v Plané dokládá činnost hrnčířské dílny na severním okraji historického jádra v období kolem poloviny 14. století. Kromě kuchyňské a stolní keramiky a nádobkových kachlů se podařilo získat i další technickou keramiku, o jejíž výrobě v dílně lze uvažovat, a to vyhřívací rouru. Do produkce této hrnčiřské dílny patřila i drobná keramická plastika doložená nálezem torza ženské figurky typu Kruseler. S provozem hrnčířské dílny bezesporu souvisí i nález keramické destičky s reliéfy pražského groše Jana Lucemburského. Právě drobná keramická plastika a keramická destička jsou dokladem snahy o vytváření výrobně složitějších produktů, než představoval běžný sortiment kuchyňské a stolní keramiky. 


\section{Prameny a literatura}

BAŠTA, J., 1991: Otázka zemských stezek na Domažlicku ve světle archeologických nálezů, Studia Medieavalia Pragensia II, 61-74.

BEUTMANN, J., 2007: Untersuchungen zu Topographie und Sachkultur des mittelalterlichen Zwickau. Die Ausgrabungen im Nordwesten des Stadtkerns. Dresden.

BLAŽKOVÁ, K.-LOMECKÁ, J., 2006: Záchranné archeologické výzkumy pozdně středověké hrnčířské pece a studny v Rakovníku, ASČ 10, 913-926.

BURIAN, V., 1963: Historickoarcheologický výzkum husitského opevnění v Dolanech u Olomouce roku 1962, Muzejní a vlastivědná práce I, 199-204.

- 1966: Předběžná zpráva o historickoarcheologickém výzkumu kartouzky v Dolanech 1964-1965. In: Zprávy vlastivědného ústavu v Olomouci 1966 (č. 128), 9-15. Olomouc.

DUDKOVÁ, V.-ORNA, J., 2007: Gotické a renesanční kachle z výzkumu horní části náměstí Republiky v Horšovském Týně v roce 2006, SZM XVIII, 217-221.

DUDKOVÁ, V.-ORNA, J.-NETOLICKÝ, P., 2015: Špitální areál sv. Máří Magdaleny v Plzni. In: Od špitálu ke galerii... Archeologické poznání vývoje lokality „U Zvonu“ v Plzni (Dudková, V.-Orna, J., edd.), 10-23. Plzeň.

FOJTÍK, P., 2010: Drobná středověká terakotová plastika ze zaniklé středověké osady Stará Ves, k. ú. Kralice na Hané, okr. Prostějov. In: Zaměřeno na středověk (Zdeňkovi Měřínskému k 60. narozeninám) (Ungerman, Š.-Přichystalová, R., edd.), 434-441. Praha.

FRÝDA, F., 1978: Planá, okr. Tachov, BZO 1975, 63.

GABRIEL, F.-KRACÍKOVÁ, L., 2010: K funkci drobné keramické plastiky - Zur Funktion von keramischen Kleinskulpturen, AH 35, 225-232.

GERLACH, S., 1998: Mittelalterliche und frühneuzeitliche Tonfiguren aus Unterfranken, Meinfränkische Studien, Band 63, 192-210.

GRIMM, G. V., ed., 2011: Kleine Meisterwerke des Bilddrucks. Ungeliebte Kinder der Kunstgeschichte. Handbuch und Katalog der Pfeifentonfiguren, Model und Reliefdrucke. Aachen.

GÜHNE, A., 1991: Stadtarchäologie in Freiberg. Holzfunde. Berlin.

HÁNA, J., 2007: Úvahy o typologii a chronologii pražských grošů Jana Lucemburského, Numismatický sborník 22, 107-114.

HANZLÍKOVÁ, H.-FRÝDA, F., 1982: Románský kostel Petra a Pavla v Plané, okr. Tachov - Romanische Peter-Paul Kirche in Planá, Bez. Tachau, AH 7, 423-426.

HAVRDA, J.-MATĚJKOVÁ, K., 2014: Hrnčíři ve středověké Praze. Výsledky výzkumu výrobních zařízení z Malé Strany v kontextu dosavadních poznatků - Töpfer im mittelalterlichen Prag. Ergebnisse einer Untersuchung von Produktionsanlagen von der Prager Kleinseite im Kontext der bisherigen Erkenntnisse, AH 39, 23-51.

HEEGE, A., ed., 2002: Einbeck im Mittelalter. Eine archäologisch-historische Spurensuche. Oldenburg.

HERMANN, M., 2004: Neues von den Augsburger „Bilderbäckern“, Knasterkopf 17, 3-20.

HOFFMANN, V., 1996: Allerlay kurtzweil - Mittelalterliche und frühneuzeitliche Spielzeugfunde aus Sachsen. In: Arbeits- und Forschungsberichte zur sächsischen Bodenkmalpflege. Band 38, 127-200. Dresden.

HRDLIČKA, L., 1967: Středověká hrnčířská pec s keramickou klenbou v Bakově nad Jizerou, AR XIX, 511-524.

HRDLIČKA, L.-RICHTER, M.-SMETÁNKA, Z., 1966: Výzkum v Sezimově Ústí v roce 1965, AR XVIII, $663-680$.

JUŘINOVÁ, Š., 2015: Lidová zbožnost pozdního středověku a novověku v odrazu hmotné kultury (na př́ikladu drobné keramické plastiky). Nepublikovaná diplomová práce, ulož. na Katolické teologické fakultě UK, Praha.

KAŠPAR, V.-ŽEGKLITZ, J., 2009: Hrnčíři z Truhlářské ulice. In: Juřina, P. a kol., Náměstí Republiky. Výzkum století, 79-83. Praha.

KUČA, K., 2002: Města a městečka v Čechách, na Moravě a ve Slezsku. V. díl. Par-Pra. Praha.

LÍBAL, D.-JIŘÍKOVÁ, H.-HEROUTOVÁ, M., 1971: Stavebněhistorický průzkum. Planá u ML - historické jádro města, SÚRPMO Praha.

MĚCHUROVÁ, Z., 1988: Drobná středověká plastika ve sbírkách Moravského muzea v Brně - Mittelalterliche Kleinplastik in den Sammlungen des Mährischen Landesmuseums in Brünn, Acta Musei Moraviae - ČMMZ LXXIII, 71-78. 
- 2016: Chvála středověké každodennosti: pohled do archeologických sbírek objektivem Silvie Doleželové Lob des mittelaterlichen Alltagslebens. Ein Blick in archäologische Sammlungen durch das Objektiv von Silvie Doleželová. Brno.

MILITKÝ, J., 1996: Zpráva o záchranných archeologických výzkumech provedených na lokalitě České Budějovice, Mariánské náměstí (novostavba České pojištovny). Rkp. ulož. v archivu Jihočeského muzea v Českých Budějovicích.

NEKUDA, V.-REICHERTOVÁ, K., 1968: Středověká keramika v Čechách a na Moravě. Brno.

NOVÁČEK, K.-ŠIROKÝ, R., 2004: Prvních sto let. Počátky Nové Plzně z pohledu archeologie, Minulostí Západočeského kraje XXXIX, 7-51.

ORNA, J., 2006: Drobná středověká figurální keramická plastika z Plzně, Muzejní a vlastivědná práce, ČSPS, č. 3-4, 206-208.

PELANT, J., 1984: Města a městečka Západočeského kraje. Stručné dějiny, současnost a výběrová bibliografie 129 míst. Plzeň.

PREUSZ, M.-ČAPEK, L., 2019. Stř̌edověké a novověké hrnčířské pece v Čechách - kritické zhodnocení výpovědních možností studia - Mittelalterliche und neuzeitliche Töpferöfen in Böhmen - eine kritische Auswertung der Aussagemöglichkeiten von Studien, AH 44, 313-355.

PROCHÁZKA, Z., 2002: Plánsko a Tachovsko. Historicko-turistický průvodce č. 17. Domažlice.

PROCHÁZKA, Z.-ÚLOVEC, J., 1990: Hrady, zámky a tvrze okresu Tachov. Tachov.

RAYMAN, N., 2010: Planá. Stavební úpravy okolí kostela Nanebevzetí Panny Marie v Plané. Nálezová zpráva, ulož. v archivu Muzea Českého lesa v Tachově.

RBM I: Regesta diplomatica nec non epistolaria Bohemiae et Moraviae I, 600-1253 (Erben, K. J., ed.). Praha 1855.

REICHERTOVÁ, K., 1962: Středověká hrnčířská dílna v Hořovicích, AR XIV, 704-705.

RICHTER, M., 1978: Středověká keramika ze Sezimova Ústí. Hluboká nad Vltavou.

RICHTER, M.-HRDLIČKA, L., 1965: Výzkum v Sezimově Ústí v roce 1964, AR XVII, 655-668.

SENFT, E., 1932: Geschichte der Herrschaft und Stadt Planin Böhmen. Planá.

SOMMER, P., 1979: Dominikánský klášter v Berouně (předběžná zpráva o výzkumu) - Das Dominikanerkloster in Beroun (Vorbericht über die archäologische Untersuchung), AH 4, 43-54.

ŠEBESTA, P., 1979: Výzkum středověké studny v Chebu - Der mittelalterliche Brunnen in Cheb, Mincovní Gasse, AH 4, 267-271.

ŠULC, J.- KYPTA, J.- JEŽEK, M., 2009: K hospodaření a kultuře bydlení na středočeském statku v raném novověku: př́iklad z Trněného Újezdu (okr. Kladno) - The possibility of studying the rural housing culture between the Middle Ages and the Early Modern period on the basis of sources from Trněný Újezd (Central Bohemia), AR LXI, 697-714.

TYMONOVÁ, M., 2003: Kachlová kamna z Náměště na Hané - Kachelofen aus Náměšt' na Hané, AH 28, 575-590.

VAŘEKA, P., 2004: Výrobní (hrnčířský?) areál z časného novověku v Berouně - České ulici čp. 56, Archeologia technica $15,78-85$.

VRÁNA, J., 2002: Kartuziánský klášter v Dolanech u Olomouce. Archeologické památky stř̌ední Moravy. Svazek 5. Olomouc.

ZELENKA, A., 2018: Planá, okr. Tachov - Tylova ulice (k otázce datace městského opevnění). In: Zprávy České archeologické společnosti. Supplément 109. Archeologické výzkumy v Čechách 2017. Sborník referátů z informačního kolokvia, 38-39. Praha.

ŽEGKLITZ, J., 1990: Topografie pražských hrnčířských dílen a jejich podoba v 16. - poč. 17. století - The topography and outlook of pottery workshops of Prague in the 16th and incipient 17th Century, Studies in Post-Medieval Archaeology 1, 215-230.

\section{Zusammenfassung}

\section{Belege für Töpfereiproduktion in der Tylova-Str. in Planá bei Mariánské Lázně}

Bei einer durch das Bauvorhaben eines Familienhauses in der Tylova-Str. in Planá bei Marienbad hervorgerufenen Rettungsgrabung wurde eine der freigelegten Fundsituationen als Scherbengrube einer Töpfereiwerkstatt interpretiert. Im Hinblick darauf, dass eine wesentliche Fundkomponente, d.h. ein Brennofen fehlte, der eine Töpferproduktion belegen würde, erfolgte 
die Analyse der Funde von der Scherbengrube und der Fundstellenlage mit dem Ziel, Indizien zu finden, welche die Tätigkeit einer Werkstatt zur Keramikproduktion belegen.

Die untersuchte Parzelle liegt am Rande des historischen Stadtkerns. Archäologisch belegte Töpferwerkstätten befanden sich auch bei einer Reihe weiterer Fundstellen in einer vergleichbaren Lage am Rande des historischen Stadtkerns, ggf. in der Nähe einer Befestigungsanlage (z.B. Pilsen, Rakovník, Hořovice, Bakov nad Jizerou, Beroun, Prag - Kleinseite, Prag - Neustadt), dies trifft besonders dann für die Zeit des 14. Jahrhunderts zu.

Die gefundenen Fragmente an Küchen- und Tafelkeramik ermöglichen eine chronologische Zuordnung des Fundkomplexes in die Zeit nach Mitte des 14. Jahrhunderts. Gerade in dieser Zeit beginnt die Herstellung von Frauenfigürchen vom Typ Kruseler. Die atypische Herstellung der gefundenen Plastiken vom Typ Kruseler durch eine Modellierung von Hand könnte eine Reaktion ihres Schöpfers auf ein neu auftretendes Keramikprodukt sein, möglicherweise mit dem Bestreben, für eine weitere Herstellung solcher Figürchen eine Form zu schaffen. Für die Töpferwerkstatt, deren Produktion während der Grabung in der Tylova-Str. in Planá erfasst werden konnte, stellte die Herstellung von kleinen Keramikplastiken offenbar nur einen marginalen Teil der Produktion dar. Darauf deutet im Übrigen auch die Ausführung des gefundenen Figürchens hin.

Auch das Keramikplättchen mit den Positiven der unter der Herrschaft von Johann von Luxemburg (1310-1346) geprägten Prager Groschen weicht chronologisch nicht ausdrücklich von der Datierung des ganzen Fundkomplexes ab. Obwohl bei Prager Groschen im Rahmen ihrer Typologie auch eine genauere chronologische Bestimmung möglich ist, ermöglicht die Qualität der Ausführung des Reliefs der Münze auf dem Keramikplättchen keine solche Präzisierung. Die Interpretation zu welchem Zweck das Plättchen gedient haben mag, ist relativ schwierig, in Betracht kommt hier vielleicht die Anfertigung eines Meisterstücks.

Keramikheizrohre konnten bereits ab dem 13. Jahrhundert in der Konstruktion eines Kachelofens verwendet werden. Die Herstellung solcher technischer Keramik in Planá bei Marienbad in der Zeit um Mitte des 14. Jahrhunderts wird auch durch einen Fund belegt, der von der in der zweiten Hälfte dieses Jahrhunderts im Bereich nördlich von der Mariä-Himmelfahrtskirche untergegangenen Bebauung stammt.

Die in der Tylova-Str. in Planá durch die archäologische Rettungsgrabung entdeckte Scherbengrube belegt für die Zeit um Mitte des 14. Jahrhunderts die Tätigkeit einer Töpferwerkstatt am nördlichen Rand des historischen Stadtkerns. Die gefundenen Artefakte sind ein Beleg dafür, dass in dieser Werkstatt herstellungstechnisch kompliziertere Produkte geschaffen wurden, als das gängige Sortiment an Küchen- und Tafelkeramik darstellte.

Mgr. Jiří Orna, Západočeské muzeum v Plzni, Kopeckého sady 2, 30100 Plzeň, Česká republika, jorna@zcm.cz

Mgr. Antonín Zelenka, Západočeské muzeum v Plzni, Kopeckého sady 2, 30100 Plzeň, Česká republika, azelenka@zcm.cz 
